\title{
Large Trees Dominate Carbon Storage in Forests East of the Cascade Crest in the United States Pacific Northwest
}

\author{
David J. Mildrexler ${ }^{*}$, Logan T. Berner ${ }^{2}$, Beverly E. Law³ ${ }^{3}$ Richard A. Birdsey ${ }^{4}$ and \\ William R. Moomaw 4,5 \\ ${ }^{1}$ Eastern Oregon Legacy Lands, Joseph, OR, United States, ${ }^{2}$ EcoSpatial Services L.L.C., Flagstaff, AZ, United States, \\ ${ }^{3}$ Department of Forest Ecosystems and Society, Oregon State University, Corvallis, OR, United States, ${ }^{4}$ Woodwell Climate \\ Research Center, Falmouth, MA, United States, ${ }^{5}$ The Fletcher School and Global Development and Environment Institute, \\ Tufts University, Medford, MA, United States
}

\section{OPEN ACCESS}

Edited by: Isabel Cañellas, Centro de Investigación Forestal (INIA), Spain

Reviewed by: Jurij Diaci, University of Ljubljana, Slovenia Thomas J. Dean, Louisiana State University, United States

*Correspondence:

David J. Mildrexler d.mildrexler@gmail.com

Specialty section:

This article was submitted to

Forest Management,

a section of the journal

Frontiers in Forests and Global

Change

Received: 12 August 2020 Accepted: 16 October 2020 Published: 05 November 2020

Citation:

Mildrexler DJ, Berner LT, Law BE, Birdsey RA and Moomaw WR (2020)

Large Trees Dominate Carbon

Storage in Forests East of the Cascade Crest in the United States

Pacific Northwest.

Front. For. Glob. Change 3:594274. doi: 10.3389/ffgc.2020.594274
Large-diameter trees store disproportionally massive amounts of carbon and are a major driver of carbon cycle dynamics in forests worldwide. In the temperate forests of the western United States, proposed changes to Forest Plans would significantly weaken protections for a large portion of trees greater than $53 \mathrm{~cm}$ (21 inches) in diameter (herein referred to as "large-diameter trees") across 11.5 million acres ( 4.7 million ha) of National Forest lands. This study is among the first to report how carbon storage in large trees and forest ecosystems would be affected by a proposed policy. We examined the proportion of large-diameter trees on National Forest lands east of the Cascade Mountains crest in Oregon and Washington, their contribution to overall aboveground carbon (AGC) storage, and the potential reduction in carbon stocks resulting from widespread harvest. We analyzed forest inventory data collected on 3,335 plots and found that large trees play a major role in the accumulated carbon stock of these forests. Tree AGC $(\mathrm{kg})$ increases sharply with tree diameter at breast height $(\mathrm{DBH}$; $\mathrm{cm}$ ) among five dominant tree species. Large trees accounted for 2.0 to $3.7 \%$ of all stems (DBH $\geq 1$ " or $2.54 \mathrm{~cm}$ ) among five tree species; but held 33 to $46 \%$ of the total AGC stored by each species. Pooled across the five dominant species, large trees accounted for $3 \%$ of the 636,520 trees occurring on the inventory plots but stored $42 \%$ of the total AGC. A recently proposed large-scale vegetation management project that involved widespread harvest of large trees, mostly grand fir, would have removed $\sim 44 \%$ of the AGC stored in these large-diameter trees, and released a large amount of carbon dioxide to the atmosphere. Given the urgency of keeping additional carbon out of the atmosphere and continuing carbon accumulation from the atmosphere to protect the climate system, it would be prudent to continue protecting ecosystems with large trees for their carbon stores, and also for their co-benefits of habitat for biodiversity, resilience to drought and fire, and microclimate buffering under future climate extremes.

Keywords: carbon, climate mitigation, eastside screens, forests, global change, large-diameter trees, 21-inch rule 


\section{INTRODUCTION}

Forest carbon accumulation is crucial for mitigating ongoing climatic change, with individual large trees storing a substantial portion of the overall carbon in living trees. Globally, forests store about $862 \mathrm{Gt}$ carbon in live and dead vegetation and soil, with $42 \%$ of it stored in live biomass (above- and belowground; Pan et al., 2011). Globally, forests removed the equivalent of about 30\% of fossil fuel emissions annually from 2009 to 2018 (Friedlingstein et al., 2019), and $44 \%$ of that was by temperate forests. Temperate forests of the United States are the largest category of land sinks in the country, consistently offsetting about $14 \%$ of the Nation's $\mathrm{CO}_{2}$ emissions (EPA, 2020). Projections indicate that ecological systems have significant additional climate mitigation potential, with forest carbon accumulation serving as a central component of a natural climate solutions framework (Griscom et al., 2017; Fargione et al., 2018; Moomaw et al., 2019; Cook-Patton et al., 2020).

Large-diameter trees constitute about half of the mature forest biomass worldwide and are key to the ability of forests to accumulate substantial amounts of carbon needed to mitigate climate change (Luyssaert et al., 2008; Lutz et al., 2018). Trees exceeding $60 \mathrm{~cm}$ (23.6 in) diameter at breast height (DBH) comprise $\sim 41 \%$ of the world's aboveground live tree biomass (Lutz et al., 2018). Furthermore, on average, 50\% of the live tree biomass carbon in all types of forests globally is stored in the largest $1 \%$ of trees, but the value for the United States is lower, $\sim 30 \%$ in the largest $1 \%$ of trees due to widespread historical logging of large trees (Lutz et al., 2018). A single large tree can add the same amount of carbon to the forest within a year as is contained in a single midsized tree of the same species (Stephenson et al., 2014). The relationship between large-diameter trees and overall forest biomass suggests that forests cannot accumulate aboveground carbon (AGC) to their ecological potential without large trees (Lutz et al., 2018). Recognition of the importance of large-diameter trees in determining global atmospheric carbon stocks has led to management recommendations to conserve existing large-diameter trees and those that will soon reach large diameters (Lindenmayer et al., 2014; Lutz et al., 2018; Moomaw et al., 2019).

In addition to comprising a substantial portion of forest carbon storage and accumulation, large-diameter trees fulfill a variety of unique ecological roles such as increasing droughttolerance, reducing flooding from intense precipitation events, altering fire behavior, redistributing soil water, and acting as focal centers of mycorrhizal communication and resource sharing networks (Bull et al., 1997; Brooks et al., 2002; Brown et al., 2004; Luyssaert et al., 2008; Beiler et al., 2015; Lindenmayer and Laurance, 2017). In the United States Pacific Northwest (PNW), carbon dense old growth forests buffer against increasing temperatures by creating microclimates that shelter understory species from rising temperatures (Frey et al., 2016; Davis et al., 2019a). Forests with large-diameter trees often have high tree species richness, and a high proportion of critical habitat for endangered vertebrate species, indicating a strong potential to support biodiversity into the future and promote ecosystem resilience to climate change (Lindenmayer et al., 2014; Buotte et al., 2020).

In the PNW region of the United States a 21 -inch $(\sim 53 \mathrm{~cm})$ diameter criteria (USDA Forest Service, 1995) was enacted in 1994 to slow the loss of large, older trees and old forest patches in national forests east of the Cascade Mountains crest in Oregon and Washington. The forests under consideration shall be referred to as "eastside forests" to be consistent with United States Forest Service (USFS) terminology. In our study, we refer to trees that equal or exceed this value to be "large-trees" or "large-diameter trees." Extensive studies determined that the large tree component of old forest structure had decreased due to human uses, and that sensitive wildlife species associated with old growth forest such as the American Marten and the Northern Goshawk were also in decline (Interior Columbia Basin Ecosystem Management Project, 2000; Wisdom et al., 2000; Bull et al., 2005; Greenwald et al., 2005). Site-specific exceptions have allowed removal of some trees $\geq 21$ in DBH. However, the 21-inch rule has prevented large-scale harvest of trees $\geq 21$ in DBH. For example, the 2010 Snow Basin Vegetation Management Project proposed harvesting over 43,000 trees $\geq 21$ in DBH but was stopped by litigation [League of Wilderness Defenders, et al., v. Connaughton, et al., No. 3:12-cv-02271-HZ (D. Or. Dec. 9, 2014)]. Recently restoration of these forests was claimed to be inhibited by the 21 -inch rule that protects large trees from logging (Hessburg et al., 2020). The rationale for harvesting large trees is premised upon the use of historical baselines of stand structure and species composition as management targets, and assuming that by removing large shade-tolerant species like grand fir and Douglas-fir it will promote resilience to future drought and disturbance (Johnston et al., 2018; Merschel et al., 2019; Hessburg et al., 2020). However, ongoing climate change and many other anthropogenic stressors such as habitat fragmentation, invasive species, and declines in biodiversity, heighten concerns over use of historical conditions as management targets (Millar et al., 2007; IPCC, 2018; Ripple et al., 2020). Proposed amendments to the 21-inch diameter limit would allow widespread harvesting of the larger trees up to 30 in DBH $(76.2 \mathrm{~cm})$ across six National Forests of eastern Oregon and southwestern Washington with major implications for forest carbon dynamics and important environmental co-benefits (Figure 1).

Carbon storage is an increasingly important management objective for National Forest Lands in the United States (Depro et al., 2008; Dilling et al., 2013; Dugan et al., 2017). USFS Forest Inventory and Analysis (FIA) data have been used to develop baseline stocks and trends of forest carbon for every region and individual National Forest, including assessment of the main disturbance, management, and environmental factors that drive changes (Birdsey et al., 2019). Western United States forests show considerable potential to accumulate additional carbon over the coming century, especially forests within the PNW that are projected to have relatively low to moderate vulnerability to future drought and fire (Figure 1; Buotte et al., 2020). Strategies to mitigate climate change effects on forests require careful examination of the tradeoffs of proposed forestry practices on forest carbon stock accumulation, water cycling, and additional environmental co-benefits of forests, such as biodiversity and 


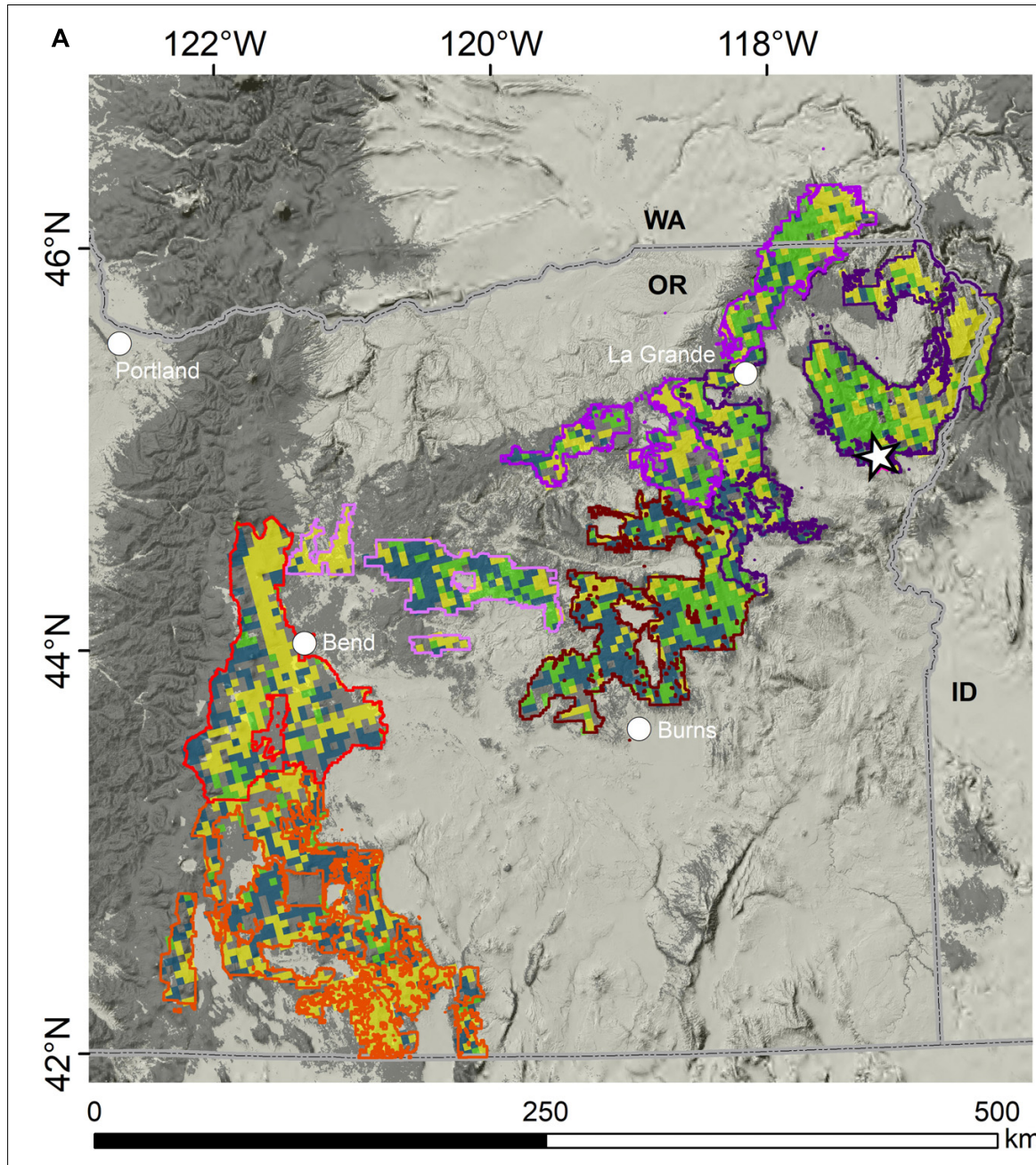

Forest Carbon Priority Rank

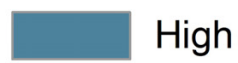

Medium

$\square$ Low

Other forest

Select populated place

出 Snow Basin Project

National Forest

Deschutes

Fremont-Winema

Malheur

Ochoco

Umatilla

Wallowa-Whitman

B

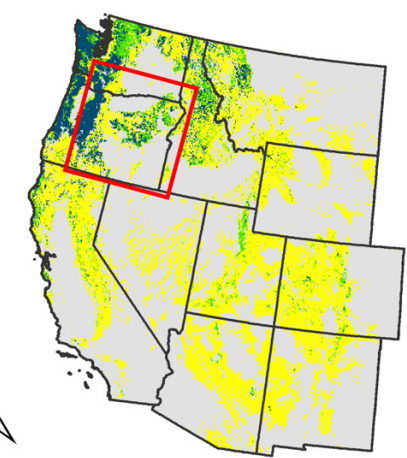

FIGURE 1 | Locations of the six national forests in eastern Oregon, southeastern Washington, and western Idaho, and the proposed Snow Basin Project area (A). The forest carbon conservation priority rank is shown for the national forests and (B) for the broader western United States. The forest carbon conservation priority rank is from Buotte et al. (2020) and was derived from simulations of potential forest carbon sequestration and vulnerability to drought and fire over the 21 st century. Forest extent is from Ruefenacht et al. (2008).

microclimatic buffering (McKinley et al., 2011; Law et al., 2018; Sheil, 2018; Buotte et al., 2020).

The potential effects of changing the 21 -inch rule on carbon storage of eastside forests have not been adequately considered. Proposed changes to the management of large trees should be carefully assessed prior to adoption of new rules given that forest carbon storage is critically important in the context of a warming climate, and that large trees disproportionately store more accumulated carbon, keeping it out of the atmosphere. The objective of this study is to evaluate the potential impact of removal of the 21-inch rule on forest carbon stocks and carbon stock accumulation in eastside forests (Figure 1). We examine the relationship between tree $\mathrm{DBH}$ and AGC storage at tree to population scales for selected dominant tree species in eastside forests, focusing on the following questions:

1. How does AGC storage change with tree diameter among the dominant eastside tree species?
2. How common are large trees across the eastside forests by species and what proportion of each species total AGC do they account for?

3. What are the potential consequences on carbon stores of widespread removal of large trees in eastside forest restoration projects?

\section{MATERIALS AND METHODS}

\section{Study Area}

Our study area included the six national forests in eastern Oregon, two of which extend slightly into southwestern Washington and western Idaho (Figure 1). Located within the East Cascades and Blue Mountains ecoregions, these national forests together cover approximately 11.5 million acres (4.7 million ha) of complex mountainous terrain, characterized by a broad range of environmental gradients in climate regimes and 
TABLE 1 | Summary of forest inventory data and climate conditions for the six National Forests included in the analysis.

\begin{tabular}{|c|c|c|c|c|c|c|c|}
\hline \multirow[t]{3}{*}{ National forest } & \multicolumn{3}{|c|}{ Forest inventory } & \multicolumn{4}{|c|}{ Climate conditions } \\
\hline & \multirow[t]{2}{*}{ N. Plots } & \multirow[t]{2}{*}{ DBH (cm) } & \multirow[t]{2}{*}{ AGC (kg) } & \multirow[t]{2}{*}{ Annual precipitation (mm) } & \multicolumn{3}{|c|}{ Temperature $\left({ }^{\circ} \mathrm{C}\right)$} \\
\hline & & & & & Annual & Jan. & July \\
\hline Deschutes & 474 & $16(187)$ & 131 (11359) & $817(170)$ & $6.1(0.6)$ & $-1.5(1.9)$ & $16.1(1.8)$ \\
\hline Fremont-Winema & 740 & 17 (204) & 145 (14269) & $681(156)$ & $6.3(0.6)$ & $-1.4(1.9)$ & $16.6(1.8)$ \\
\hline Malheur & 687 & $15(145)$ & 108 (8392) & $571(104)$ & $5.9(0.7)$ & $-2.9(2.0)$ & $17.2(2.1)$ \\
\hline Ochoco & 253 & $16(188)$ & $119(13462)$ & $484(101)$ & $7.1(0.6)$ & $-1.0(1.9)$ & $17.6(1.9)$ \\
\hline Umatilla & 487 & $14(139)$ & 99 (8759) & $802(121)$ & $6.8(0.7)$ & $-1.5(1.8)$ & $17.5(2.0)$ \\
\hline Wallowa-Whitman & 694 & $13(164)$ & 91 (8301) & $792(119)$ & $6.0(0.7)$ & $-3.0(1.8)$ & $17.3(2.1)$ \\
\hline
\end{tabular}

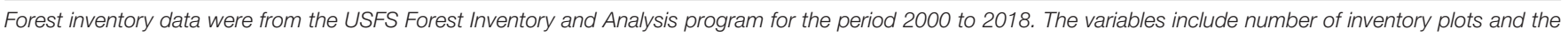

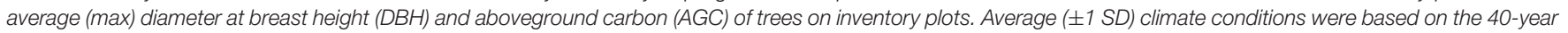
period from 1981 to 2019 and derived from 4-km resolution gridded PRISM data (Daly et al., 2008).

associated forest types (Johnson and Clausnitzer, 1992; Peterson and Waring, 1994; Berner and Law, 2015). The Blue Mountains ecoregion functions ecologically and floristically as a transverse bridge between the Cascade Mountains to the west and the Rocky Mountains to the east (Kerns et al., 2017). This "mega-corridor" links together some of the most intact habitat remaining in the PNW region and is of great importance to regional-scale connectivity and carbon storage in response to a warming climate (McGuire et al., 2016; Buotte et al., 2020).

Climatic conditions from 1981 to 2019 were similar across National Forests with regard to January and July average temperatures but show substantial variation in annual precipitation (Table 1). The Deschutes and Fremont-Winema National Forests are in the eastern Cascade Mountains and thus receive relatively high annual precipitation $(817 \mathrm{~mm}$ and $681 \mathrm{~mm}$ ) due to orographic uplift. National Forests in the southwestern Blue Mountains receive less precipitation (Malheur, $571 \mathrm{~mm}$; Ochoco, $484 \mathrm{~mm}$ ) due to their location within the rainshadow of the Cascade Mountains. In the northeastern portion of our study area annual precipitation increases to $802 \mathrm{~mm}$ and $792 \mathrm{~mm}$, respectively, for the Umatilla and Wallowa Whitman National Forests due to the intrusion of moistureladen air masses through the Columbia River Gorge. The region's complex precipitation patterns are similarly reflected in the distribution of forest types and biophysical characteristics.

\section{Forest Inventory and Analysis Dataset}

We relied on forest inventory measurements from the USFS FIA program and our own selection of biomass equations to evaluate relationships between tree diameter and AGC storage, as well as assess potential effects of tree removal proposed as part of the 2010 Snow Basin project. The FIA conducts systematic forest inventories across the United States, with one field sampling plot for every $\sim 2,400$ hectares (6,000 acres) of forest (O'Connell et al., 2017). In the western United States, the FIA surveys $10 \%$ of sampling plots each year, meaning that each sampling plot is revisited every 10 years. At each sampling plot, field crews collect data on tree species, tree size, and other forest attributes. These inventory data are available online through the FIA DataMart ${ }^{1}$.

${ }^{1}$ https://apps.fs.usda.gov/fia/datamart/
We downloaded the latest FIA data (FIADB_1.8.0.02) for Oregon, Washington, and Idaho, and then identified inventory plots that occurred within the six national forests based on a spatial overlay with national forest boundaries ( $n=3,973$ plots). To maintain landowner privacy the FIA plot coordinates available to the public are slightly altered ("fuzzed"), thus our spatial overlay may include some plots just outside the national forests or miss some plots that occur around the edges of these forests. We selected the latest inventory measurements from each surveyed plot for the years 2010 to 2018 (the most recent year available). We filtered these data to include only live trees of the five tree species of interest. A total of 54,651 individual trees were measured on the microplots, subplots, and macroplots, which represented 636,520 trees after applying the expansion factors for each type of plot. Overall, we used data from 3,335 plots in this analysis. A summary of FIA plot conditions within our study area shows that relatively small variations in average $\mathrm{DBH}$ across National Forests, between $13 \mathrm{~cm}$ and $17 \mathrm{~cm}$, translate into substantial differences in AGC (Table 1). The Fremont Winema National Forest had the largest average DBH $(\sim 17 \mathrm{~cm})$ and the largest average AGC stores $(\sim 145 \mathrm{~kg})$, whereas the WallowaWhitman had the smallest average $\mathrm{DBH}(\sim 13 \mathrm{~cm})$ and the smallest average AGC stores ( $\sim 91 \mathrm{~kg})$.

We performed the analysis using the statistical software $\mathrm{R}$ (v. 3.6.1; R Core Team, 2020) with add-on packages including data.table (Dawle and Srinivasan, 2019), ggplot2 (Wickham, 2016), maptools (Bivand and Lewin-Koh, 2019), raster (Hijmans, 2019), and rgdal (Bivand et al., 2019).

\section{Estimating Tree Aboveground Carbon Storage}

We estimated AGC storage (AGC; $\mathrm{kg} \mathrm{C}$ ) for each tree on the FIA inventory plots using tree biometric measurements from FIA along with species- and component-specific biomass allometric models and traits (Supplementary Tables 1, 2). Using speciesspecific allometric models that include height measurements are essential to capture climate and site effects on taper and height (volume), and reduce uncertainty compared to estimates that are diameter-based and generalized models. For example, Van Tuyl et al. (2005) found that generalized models underestimated 
biomass by $50 \%$ on the eastside. Specifically, for each tree we estimated AGC as the sum of carbon stored in stem, branch, bark, and foliage biomass. To estimate stem biomass, we first derived stem volume using species-specific allometric models that incorporated tree diameter and height (Cochran, 1985; Supplementary Table 1). We then converted stem volume to biomass using published information on the wood density of each species, which we found was important to reducing uncertainty in estimates (Van Tuyl et al., 2005; Ross, 2010; Berner and Law, 2015). We also estimated branch, bark, and foliage biomass using species-specific allometric models, substituting equations for similar species where necessary (Gholz et al., 1979; Means et al., 1994; Jenkins et al., 2004). We assumed dry stem, branch, and bark biomass was 47.6 to $52.5 \%$ carbon depending on species (Lamlom and Savidge, 2003) and that dry foliage biomass was 46.1 to $51.4 \%$ carbon depending on species (Berner and Law, 2016). For trees smaller than $10 \mathrm{~cm} \mathrm{DBH}$, total aboveground biomass was estimated from tree height and then converted to AGC assuming wood carbon content.

\section{Tree-Level Analysis of Relationship Between Tree Diameter and Aboveground Carbon}

To better understand how carbon storage varies with tree size in eastside forests, we examined relationships between tree diameter (DBH; cm) and aboveground carbon (AGC; kg) among trees sampled on the FIA plots. Specifically, we rounded the $\mathrm{DBH}$ of each tree to the nearest centimeter and then computed the average AGC of trees within each $1-\mathrm{cm}$ size class. To account for sampling uncertainty, we repeatedly computed these metrics using a resampling approach where each draw $\left(n=10^{4}\right)$ utilized data from a random $25 \%$ of inventory plots sampled with replacement. We computed the median across these $10^{4}$ draws as our best-estimate of these metrics and also derived 95\% confidence intervals.

\section{Population-Level Analysis of Tree Diameter and Aboveground Carbon}

We evaluated how the cumulative percentage of tree stems and AGC varied with tree diameter across the six national forests of our study area using forest inventories. This involved quantifying the cumulative percentage of tree stems and total AGC by $\mathrm{DBH}$ for each tree species, as well as pooled across tree species. To account for sampling uncertainty, we again implement a resampling approach $\left(n=10^{4}\right.$ draws).

\section{Snow Basin Case Study: Carbon Consequences of Proposed Large Tree Removal}

To estimate the carbon consequences of large tree removal we utilized USFS National Environmental Policy Act (NEPA) documentation from the Snow Basin Vegetation Management Project located on the Wallowa-Whitman National Forest, Whitman Ranger District, Baker County, Oregon (Figure 1). The project area includes 10,721 ha (26,493 acres) of National Forest land and primarily encompasses two main subwatersheds (Paddy
Creek-Eagle Creek and Little Eagle Creek). Elevations within the project area range from approximately $1,340 \mathrm{~m}$ (4,400 feet) on the southern boundary to approximately $1,980 \mathrm{~m}$ (6,500 feet) at the northern boundary near the border with the Eagle Cap Wilderness. The USFS's preferred alternative plan was to remove over 43,000 large trees $(\mathrm{DBH} \geq 21$ in or $53.3 \mathrm{~cm}$ ) from the project area. The large tree removal was prevented by litigation, but the project nonetheless provides a realistic framework to evaluate the carbon cost of large tree removal associated with dry forest landscape-scale restoration projects.

The Snow Basin NEPA document estimated the number of large trees to be removed or retained per acre by biophysical environment (Snow Basin DEIS). The USFS's preferred alternative proposed removal of grand fir from $\mathrm{cool} / \mathrm{moist}$ and warm/dry grand fir biophysical environments, as well as removal of ponderosa pine, Douglas-fir, and western larch from mixed ponderosa pine and Douglas-fir biophysical environments (Table 2). Based on this information we computed the total number of large trees proposed for removal vs. retention across the project area by biophysical environment. To evaluate the potential carbon consequences of large tree removal, it was necessary to know tree size class distribution. The FIA only surveyed 13 plots in the Snow Basin project area between 2010 and 2018, of which 12 plots included large trees. After an initial analysis, we deemed this inadequate for rigorous assessment of tree size class distribution and therefore used tree measurements from all FIA plots in the Wallowa-Whitman National Forest that included large trees for the species of interest $(n=217$ plots). To estimate the size class distribution of large trees, we computed the fraction of large trees that occurred at $0.1 \mathrm{~cm} \mathrm{DBH}$ intervals between $53.3 \mathrm{~cm}$ and the largest observed $\mathrm{DBH}$ for grand fir, and after combining ponderosa pine, Douglas-fir, and western larch into a mixed-species group. For each biophysical environment, we then distributed the large trees proposed for removal or retention among these size classes in proportion to the occurrence of trees in each size class. Lastly, we estimated the total large tree AGC that would be removed or retained by multiplying the number of trees in each size class by the mean AGC of trees in that size class and then summing AGC across size classes. To account for sampling uncertainty, we again computed these metrics using a resampling approach where each of $10^{4}$ draws utilized data from a random $25 \%$ of inventory plots sampled with replacement. As before, we computed the median across these $10^{4}$ draws as our best-estimate and derived 95\% confidence intervals. For verification, we also performed this assessment using only FIA plots in the Snow Basin Project area rather than across the Wallowa-Whitman National Forest and present these findings in the Supplementary Material.

\section{RESULTS}

\section{Relationships Between Tree Diameter and Aboveground Carbon}

Average tree aboveground carbon (AGC; kg) rapidly increased with tree diameter at breast height $(\mathrm{DBH} ; \mathrm{cm})$ among dominant tree species measured on USFS inventory plots located in the 
TABLE 2 | The total number of trees $\geq 21$ in DBH proposed for removal and retention across the Snow Basin project area as reported in the NEPA plan prepared by the USFS (Table 53 of Snow Basin Vegetation Management Project DEIS, 2011).

\begin{tabular}{|c|c|c|c|c|c|c|}
\hline \multirow{2}{*}{$\begin{array}{l}\text { Biophysical } \\
\text { environment }\end{array}$} & \multirow[t]{2}{*}{ Acres treated } & \multirow{2}{*}{$\begin{array}{l}\text { Species } \\
\text { removed }\end{array}$} & \multicolumn{2}{|c|}{ Mean number of large trees per acre } & \multicolumn{2}{|c|}{ Total number of large trees } \\
\hline & & & Removed & Retained & Removed & Retained \\
\hline Cool/moist grand fir & 973 & Grand fir & 5 & 9 & 4,865 & 8,757 \\
\hline Warm/dry grand fir & 5,262 & Grand fir & 5 & 5 & 26,310 & 26,310 \\
\hline $\begin{array}{l}\text { Warm/dry } \\
\text { Douglas-fir and } \\
\text { ponderosa pine } \\
\text { Warm/moist } \\
\text { Douglas-fir }\end{array}$ & 6,136 & $\begin{array}{l}\text { Douglas-fir, } \\
\text { ponderosa } \\
\text { pine, western } \\
\text { larch }\end{array}$ & 2 & 3 & 12,272 & 18,408 \\
\hline Grand total & 12,371 & - & - & - & 43,447 & 53,475 \\
\hline
\end{tabular}

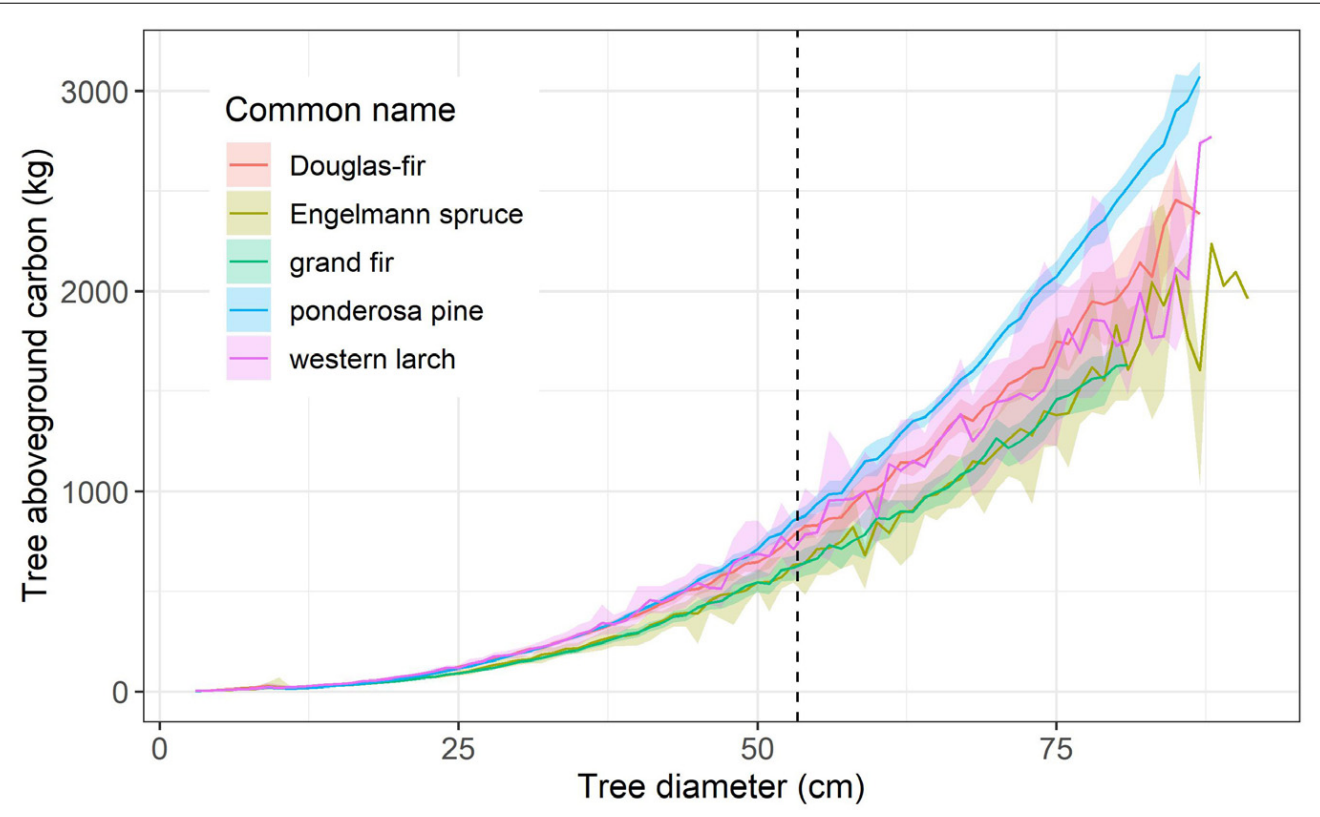

FIGURE 2 | Average tree aboveground carbon (AGC; kg) increases sharply with tree diameter at breast height (DBH; cm) for five dominant tree species measured on USFS inventory plots located in the six eastside national forests. The 21 -inch $(53.3 \mathrm{~cm}) \mathrm{DBH}$ limit of the Eastside Screens (vertical dash line) is shown for reference. Tree AGC ( $\geq 10 \mathrm{~cm} \mathrm{DBH}$ ) was estimated from tree diameter and height using regional species-specific allometric equations, wood density, and carbon content. Similarly, sapling AGC (DBH = 3-9.9 cm) was estimated from sapling height using regional species-specific allometry and wood carbon content. These estimates and $95 \%$ confidence intervals were derived by resampling $\left(n=10^{4}\right)$ measurements from inventory plots $(n=3,335)$. For visual clarity, the tree diameter limit for each species excludes the largest $0.5 \%$ of trees, generally those larger than 80 to $88 \mathrm{~cm} \mathrm{DBH}$.

six eastside national forests (Figure 2). For instance, an average $25 \mathrm{~cm}(\sim 10$ ") diameter tree stored 90-121 kg of AGC depending on tree species, while a $50 \mathrm{~cm}(\sim 20$ ") diameter tree stored 541-683 kg of AGC. Thus, doubling tree diameter over this range led to a 5.3-6.2-fold increase in AGC. Similarly, tripling tree diameter from $25 \mathrm{~cm}$ to $75 \mathrm{~cm}$ led to a 13.8-18.2-fold increase in AGC, with the largest increase observed for ponderosa pine. For any given diameter, ponderosa pine, Douglas-fir and western larch tended to store more AGC than an Engelmann spruce or grand fir.

These results clearly showed that for large trees, a small increase in diameter corresponds to a massive increase in additional carbon storage relative to a small tree increasing by the same diameter increment. Overall, as trees grow larger, each additional centimeter of stem diameter corresponds with a progressively larger increase in tree carbon storage.

\section{Tree Diameter and Aboveground Carbon Storage Within Tree Populations}

Large trees $(\mathrm{DBH} \geq 21$ in or $53.3 \mathrm{~cm}$ ) accounted for a small percentage of each species' tree stems, but a substantial percentage of the total AGC stored by each species on FIA inventory plots located in the six eastside national forests (Figure 3 and Table 3). Specifically, large trees accounted for $\sim 2.0$ to $\sim 3.7 \%$ of all stems ( $\mathrm{DBH} \geq 1$ " or $2.54 \mathrm{~cm}$ ) among the five dominant tree species; however, these trees held $\sim 33.3$ to $\sim 45.8 \%$ of the total AGC stored by each species (Table 3 ). Grand 

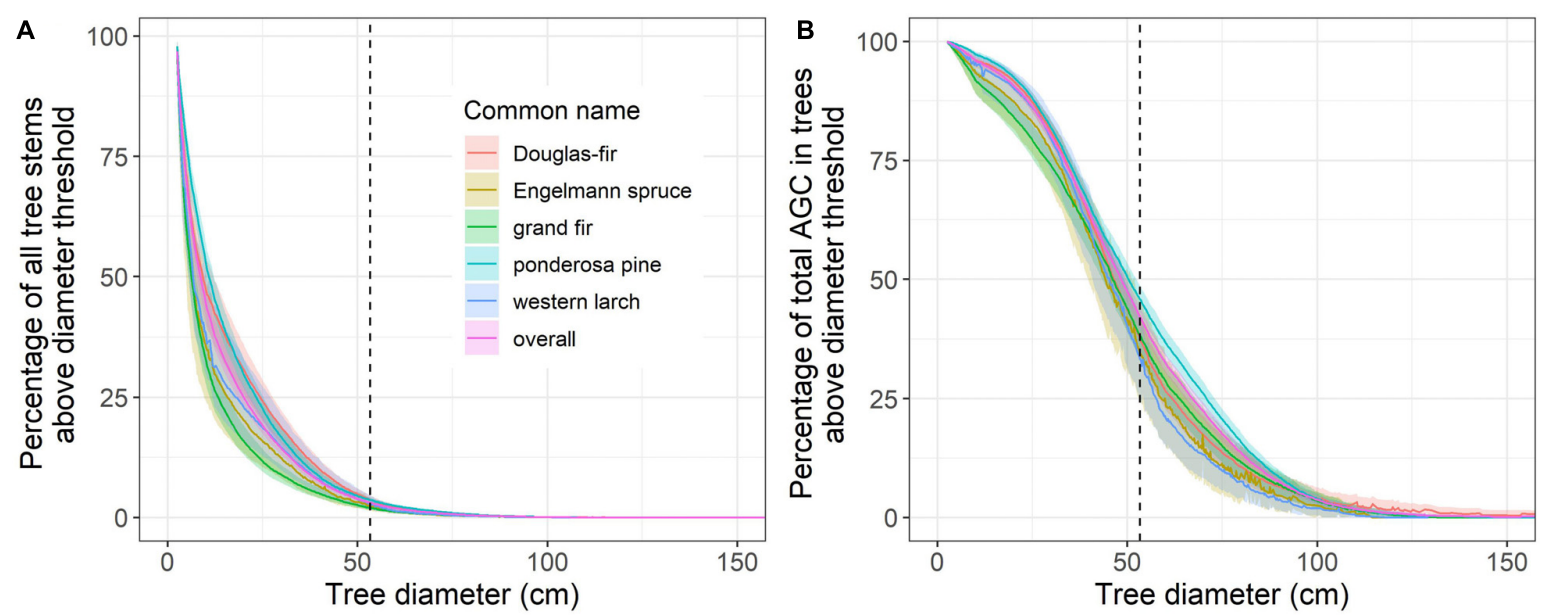

FIGURE 3 | Percentage of (A) all tree stems and (B) total aboveground carbon that occur in trees above a given diameter threshold by species based on measurements from USFS inventory plots located in the six eastside national forests. The dashed vertical lines represent a 21 in (53.3 $\mathrm{cm})$ tree DBH. These estimates and 95\% confidence intervals were derived by resampling $\left(n=10^{4}\right)$ measurements from inventory plots $(n=3,335)$. For example, trees with $\geq 21$ in diameter represent $3.7[3.2,4.2] \%$ of all ponderosa pine and account for $45.8[42.8,48.8] \%$ of all aboveground carbon stored by this species on these inventory plots. Only $\sim 0.002 \%$ of trees exceeded $150 \mathrm{~cm}$ diameter, so for visual clarity we limited the $x$-axis to $150 \mathrm{~cm}$.

TABLE 3 | Percentage of all trees stems and total aboveground carbon (AGC) occurring in trees above and below the 21 in DBH threshold based on measurements from USFS inventory plots located in the six eastside national forests.

\begin{tabular}{|c|c|c|c|c|c|}
\hline \multirow[t]{2}{*}{ Common name } & \multirow[t]{2}{*}{ Number of trees in the population } & \multicolumn{2}{|c|}{$\%$ of total species stems in trees... } & \multicolumn{2}{|c|}{$\%$ of total species AGC in trees... } \\
\hline & & $<21$ in & $\geq 21$ in & $<21$ in & $\geq 21$ in \\
\hline Douglas-fir & 100021 & $96.3[95.4,97.1]$ & $3.7[2.9,4.6]$ & $62.5[58.2,66.7]$ & $37.5[33.3,41.8]$ \\
\hline Engelmann spruce & 31375 & $97.6[96.0,98.6]$ & $2.4[1.4,4.0]$ & $65.3[54.6,75.5]$ & $34.7[24.5,45.4]$ \\
\hline Grand fir & 187445 & $98.0[97.5,98.5]$ & $2.0[1.5,2.5]$ & $61.6[57.0,66.2]$ & $38.4[33.8,43.0]$ \\
\hline Ponderosa pine & 286970 & $96.3[95.8,96.8]$ & $3.7[3.2,4.2]$ & $54.2[51.2,57.2]$ & $45.8[42.8,48.8]$ \\
\hline Western larch & 30708 & $97.2[95.5,98.4]$ & $2.8[1.6,4.5]$ & $66.7[58.4,74.8]$ & $33.3[25.2,41.6]$ \\
\hline Overall & 636520 & $96.9[96.6,97.3]$ & $3.1[2.7,3.4]$ & $57.8[55.7,60.0]$ & $42.2[40.0,44.3]$ \\
\hline
\end{tabular}

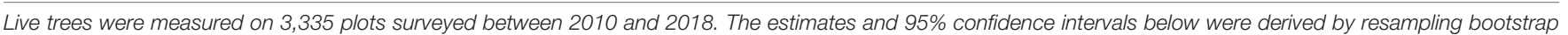
sampling. Each bootstrap sample $\left(n=10^{4}\right)$ utilized measurements from $25 \%$ of inventory plots selected at random.

fir had the lowest percentage of stems $\geq 21$ in $\mathrm{DBH}(\sim 2.0 \%)$, while ponderosa pine and Douglas-fir had the highest percentage of stems exceeding this threshold (both $\sim 3.7 \%$ ). However, large grand fir trees accounted for $38.4 \%$ of total species AGC, whereas large Douglas-fir accounted for $37.5 \%$ of total species AGC. Western larch had the lowest percentage of total species AGC in trees $\geq 21$ in $(\sim 33.3 \%)$, whereas ponderosa pine had the highest percentage $(\sim 45.8 \%)$.

Pooling across the five dominant species, large trees accounted for $\sim 3.1 \%$ of the 636,520 trees occurring on the inventory plots, but stored $\sim 42.2 \%$ of the total AGC. Similarly, based on the FIA's CRM method, the five tree species together accounted for 44.9\% of total AGC, with species-specific AGC stores ranging from $\sim 36.5$ to $\sim 49.3 \%$ of the total stored by each species (Supplementary Table 3 and Supplementary Figure 1).

A similar examination for trees $>30$ in $\mathrm{DBH}(76.2 \mathrm{~cm})$ showed that among the five species, trees larger than 30 in $\mathrm{DBH}$ accounted for $0.4-0.9 \%$ of stems, but held $\sim 9.0$ to $\sim 19.0 \%$ of each species AGC (Table 4). Ponderosa pine had the highest percentage of stems $>30$ in $\mathrm{DBH}(\sim 0.9 \%)$ and accounted for the highest percentage of AGC $(\sim 19.4 \%)$ among the five species. Douglas-fir had $\sim 0.6 \%$ of stems $>30$ in $\mathrm{DBH}$, and these stems held $\sim 12.9 \%$ of total species AGC. Engelmann Spruce, grand fir, and western larch each had $\sim 0.4 \%$ stems $>30$ in $\mathrm{DBH}$, and accounted for $\sim 10.3, \sim 14.0$, and $\sim 9.2 \%$ of each species total AGC, respectively. Overall, trees $>30$ in $\mathrm{DBH}$ represent $0.6 \%$ of stems on inventory plots, but stored $16.6 \%$ of the total AGC.

\section{Snow Basin Case Study: Carbon Consequences of Proposed Large Tree Removal}

As per the USFS NEPA documentation, the Snow Basin project preferred alternative would have removed $\sim 43,447$ large trees $(\mathrm{DBH} \geq 21$ in or $53.3 \mathrm{~cm})$ across 12,371 acres, while retaining $\sim 53,475$ large trees over this area (Table 2 ). We estimate this would translate into removing $\sim 131.3 \mathrm{Gg}$ AGC stored in large trees, while retaining $\sim 164.1 \mathrm{Gg}$ AGC in large trees $\left(1 \mathrm{Gg}=10^{9} \mathrm{~g}\right.$; Table 5). Grand fir from cool-moist and warm-dry environments would together comprise $\sim 67 \%(\sim 87.3 \mathrm{Gg}$ C) of large tree AGC 
TABLE 4 | Percentage of all tree stems and total aboveground carbon (AGC) occurring in trees above and below the 30 in diameter threshold based on measurements from USFS inventory plots located in the six eastside national forests.

\begin{tabular}{|c|c|c|c|c|c|}
\hline \multirow[t]{2}{*}{ Common name } & \multirow[t]{2}{*}{ Number of trees in the population } & \multicolumn{2}{|c|}{$\%$ of total species stems in trees... } & \multicolumn{2}{|c|}{$\%$ of total species AGC in trees... } \\
\hline & & $<30$ in & $>30$ in & $<30$ in & $>30$ in \\
\hline Douglas-fir & 100021 & $99.4[99.2,99.5]$ & $0.6[0.5,0.8]$ & $87.1[83.7,90.2]$ & $12.9[9.8,16.3]$ \\
\hline Engelmann spruce & 31375 & $99.6[99.2,99.9]$ & $0.4[0.1,0.8]$ & $89.7[82.7,95.7]$ & $10.3[4.3,17.3]$ \\
\hline Grand fir & 187445 & $99.6[99.5,99.7]$ & $0.4[0.3,0.5]$ & $86.0[82.3,89.3]$ & $14.0[10.7,17.7]$ \\
\hline Ponderosa pine & 286970 & $99.1[99.0,99.3]$ & $0.9[0.7,1.0]$ & $80.6[78.3,82.7]$ & $19.4[17.3,21.7]$ \\
\hline Western larch & 30708 & $99.6[99.3,99.8]$ & $0.4[0.2,0.7]$ & $90.8[86.2,94.8]$ & $9.2[5.2,13.8]$ \\
\hline Overall & 636520 & $99.4[99.3,99.4]$ & $0.6[0.6,0.7]$ & $83.4[81.8,85.0]$ & $16.6[15.0,18.2]$ \\
\hline
\end{tabular}

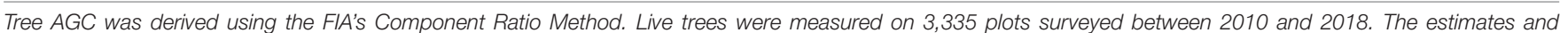

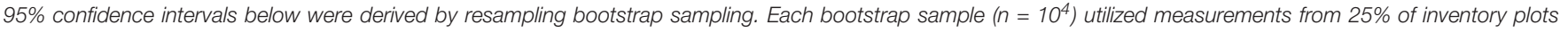
selected at random.

TABLE 5 | Removal and retention of aboveground carbon (AGC) in large trees (DBH $\geq 21 \mathrm{in})$ within the proposed Snow Basin project area.

\begin{tabular}{|c|c|c|c|c|c|}
\hline \multirow[t]{2}{*}{ Common name } & \multirow[t]{2}{*}{ Env. } & \multicolumn{2}{|c|}{ Total AGC in large trees (Gg C)... } & \multicolumn{2}{|c|}{$\%$ of large tree AGC... } \\
\hline & & Removed & Retained & Removed & Retained \\
\hline Grand fir & Cool moist & $13.6[12.0,15.3]$ & $24.5[21.6,27.5]$ & $35.7[35.7,35.7]$ & $64.3[64.3,64.3]$ \\
\hline Grand fir & Warm dry & $73.7[65.0,82.5]$ & $73.7[65.0,82.5]$ & $50.0[50.0,50.0]$ & $50.0[50.0,50.0]$ \\
\hline Douglas-fir + ponderosa pine + western larch & Warm dry or moist & $43.8[40.5,47.3]$ & $65.7[60.8,71.0]$ & $40.0[40.0,40.0]$ & $60.0[60.0,60.0]$ \\
\hline Overall & - & $131.3[120.8,141.5]$ & $164.1[151.8,176.2]$ & $44.4[44.2,44.7]$ & $55.6[55.3,55.8]$ \\
\hline
\end{tabular}

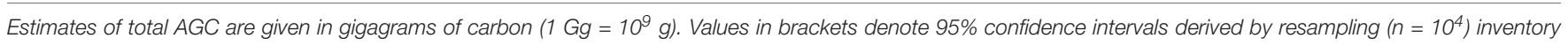
plots used to determine tree size class distributions.

removed by the project, while ponderosa pine, Douglas-fir, and western larch from warm-dry and warm-moist environments would comprise the remaining $\sim 33 \%(\sim 43.8 \mathrm{Gg} \mathrm{C})$. The project would have the largest relative and absolute impact on grand fir occurring in warm-dry environments, where $50 \%(\sim 73.7 \mathrm{Gg} \mathrm{C})$ of large tree AGC would be removed. We obtained similar results albeit with substantially wider confidence intervals using only FIA inventory plots occurring in the Snow Basin project area (Supplementary Table 4).

\section{DISCUSSION}

Our study reveals the large carbon stocks associated with largediameter trees in the region, and the potential for significant losses in AGC with large tree logging. The 21-inch rule was initially conceived to protect remaining late successional and old-growth forest and the native species that depend on these unique ecosystems for survival in forests east of the Cascades Crest in Oregon and Washington (Henjum et al., 1994). The carbon storage associated with the 21 -inch rule on the six national forests is a significant co-benefit of this protective measure. Large trees $(\mathrm{DBH} \geq 21$ in or $53.3 \mathrm{~cm}$ ) constitute $\sim 3 \%$ of the total stems, but store $\sim 42 \%$ ( $\sim 45 \%$ with CRM; Supplementary Table 3 ) of the AGC across the six eastside forests (Table 3). This finding highlights the important role of large trees in storing carbon in eastside forest ecosystems, and is consistent with previous findings on the disproportionately important role of large trees in the forest carbon cycle (Hudiburg et al., 2009; Lutz et al., 2012, 2018; Stephenson et al., 2014). The sharp increase in carbon storage with increasing tree diameter (Figure 2) speaks to the importance of preserving mature and old large trees to keep this carbon stored in the forest ecosystem where it remains for centuries (Law et al., 2018; Lutz et al., 2018). Once trees attain large stature, each additional DBH increment results in a significant addition to the tree's total carbon stores, whereas small-diameter trees must effectively ramp up to size before the relationship between DBH and AGC results in significant carbon gains. Harvest of large-diameter trees, even focused on a specific species (e.g., grand fir) can remove upward of $50 \%$ of the large tree AGC from these ecosystems (Table 5).

There are substantial differences in wood density among the species examined that contributes to the observed differences in AGC at a given $\mathrm{DBH}$. Wood density tends to be higher for ponderosa pine $\left(\sim 0.45 \mathrm{~g} \mathrm{~cm}^{3}\right)$, Douglas-fir $\left(\sim 0.52 \mathrm{~g} \mathrm{~cm}^{3}\right)$, and western larch $\left(\sim 0.56 \mathrm{~g} \mathrm{~cm}^{3}\right)$ than for Engelmann spruce $(\sim 0.37 \mathrm{~g}$ $\left.\mathrm{cm}^{3}\right)$ or grand fir $\left(\sim 0.40 \mathrm{~g} \mathrm{~cm}^{3}\right.$; Supplementary Table 2$)$. An evaluation of the relationship between tree height and diameter suggests the observed differences in AGC are not driven by ponderosa pine, Douglas-fir and western larch tending to be taller at a given DBH than Engelmann spruce or grand fir. Although stem decay is common in mature and old grand fir, a synthesis shows no evidence of carbon consequences of heart rot in grand fir (Harmon et al., 2008). While we could not estimate heart rot loss in grand fir due to lack of sufficient data, heart rot respiration has been estimated for another species and it had a scant contribution to ecosystem respiration (Harmon et al., 2004). 
Forestry practices exert significant controls on stand structure and forest carbon dynamics, and alterations of harvest practices can substantially alter carbon storage and accumulation (Masek et al., 2011; Turner et al., 2011; Krankina et al., 2012; Kauppi et al., 2015; Law et al., 2018). Generally, there is a negative relationship between harvest intensity and forest carbon stocks whereby as harvest intensity increases, forest carbon stocks decrease while emissions increase (Hudiburg et al., 2009; Mitchell et al., 2009; Simard et al., 2020). It can take centuries to reaccumulate forest carbon stocks reduced by harvest (Birdsey et al., 2006; McKinley et al., 2011). It would take 180 to 310 years to reach maximum biomass in the Blue Mountains and East Cascades, respectively, after harvest of the large trees (Hudiburg et al., 2009), too long to help reach climate mitigation targets in the next few decades. The amount of harvested carbon that remains stored in wood products is insufficient to offset the loss of carbon stored in the forest. If harvested, life cycle assessment shows that $65 \%$ of the wood harvested in Oregon over the past 115 years has been emitted to the atmosphere, $16 \%$ is in landfills and only $19 \%$ remains in wood products (Hudiburg et al., 2019). Thus, harvesting the large trees will increase, not decrease emissions and end centuries of long-term carbon storage in the forests.

The 21-inch rule has preserved the trees that store and accumulate a disproportionately large amount of carbon in these forests (Figure 3 and Table 3). Of the $\sim 3 \%$ of tree stems over 21 in DBH in the study area, about $81 \%$ of these are between 21 in and 30 in DBH and account for $\sim 61 \%$ of the AGC in all large trees (Supplementary Figure 2). Trees over 30 inches DBH account for $\sim 19 \%$ of the large tree stems and hold $\sim 39 \%$ of AGC in large trees. These findings are similar to those reported by Stephenson et al. (2014) and emphasize the relative importance of the sub-30 in DBH large trees in the study area, and the value in allowing these trees to continue growing and replenish the stock of trees over 30 inches DBH that are rare on the landscape. This proforestation strategy is among the most rapid means for accumulating additional quantities of carbon in forests and out of the atmosphere (Moomaw et al., 2019).

The importance of forest carbon storage is now greatly amplified by a warming climate that must urgently be addressed with reductions in greenhouse gasses and natural climate solutions (IPCC, 2018; Ripple et al., 2020). The preponderance of forests in our study area have medium to high carbon accumulation potential and low future climatic vulnerability (Figure 1), which reinforces the value of protecting large trees to help abate our current trajectory toward massive global change (Fargione et al., 2018; Buotte et al., 2020). Rather than holding ecosystems to an idealized conception of the past using historical conditions as management targets, a good understanding of the environmental co-benefits associated with large tree protection is needed to inform management strategies that contribute toward solving humanity's most pressing Earth system challenges (Millar et al., 2007; Rockström et al., 2009; Barnosky et al., 2017; Ripple et al., 2020). Replacing large diameter trees with seedlings will create a major carbon loss to the atmosphere during harvest (Harris et al., 2016) and not achieve storage of comparable atmospheric carbon for the indefinite future.
Large grand fir trees $(\mathrm{DBH} \geq 21$ in or $53.3 \mathrm{~cm})$ accounted for the lowest proportion of tree stems for the five species we evaluated (2\%), possibly reflecting the ingrowth of young, small grand fir within portions of our study area (Merschel et al., 2014; Johnston et al., 2016). One of the main premises for the proposed removals of large-diameter grand fir trees is that they have increased over historic levels, especially in drier biophysical environments. However, our data does not indicate an uncharacteristic abundance of large grand fir trees across these forests. Given the recent history of high-grade logging that focused on large and old trees (Henjum et al., 1994; Rainville et al., 2008), historical abundances of large trees were much greater than today (Wales et al., 2007; Hagmann et al., 2013; Kauppi et al., 2015), and thus would have represented a larger fraction of aboveground biomass than currently found on these forests.

Interestingly, with respect to the overall representation of species abundance based on inventory plots (Table 3), the population of grand fir with 187,445 stems is a distant second to ponderosa pine with 286,970 stems, followed by Douglas-fir (100,021 stems), Engelmann spruce (31,375 stems), and western larch $(30,708$ stems). To the extent that current forest stand structure is skewed toward smaller diameter classes, ponderosa pine, grand fir, and Douglas-fir trees are notable for the number of trees on inventory plots.

It is important to note that a diameter limit that emphasized protection of carbon stores would ideally protect trees starting at a lower DBH limit ( $\sim 12-15$ inches). The 21 -inch rule has provided significant leeway for fuels reduction and ecological restoration toward historical baselines to proceed in eastside forests. Ecological restoration treatments generally recommend giving protection to large and old trees, while reducing surface and ladder fuels, and accompanied by understory thinning treatments where appropriate and reintroduction of lowintensity fire at intervals (Allen et al., 2002; Brown et al., 2004; Agee and Skinner, 2005; Noss et al., 2006). From a forest carbon perspective, it would be prudent to restore an appropriate number of the approximately $97 \%$ of tree stems $<21$ inches DBH to replenish the stock of large trees over time (Lutz et al., 2018; Moomaw et al., 2019), while continuing to protect large trees for their carbon stores and the myriad other benefits that they provide. This approach would achieve the benefits of proforestation in the larger, most fire-resistant trees and reduction of fuel loads and stem density in the smaller diameter tree stems.

The Snow Basin project provides a case study for how amending the 21-inch rule to allow logging large trees could change management across the six eastside National Forests. Overall the Snow Basin project would have removed $44 \%$ or 131,000 metric tons of carbon stored in large trees. This is equivalent to $\sim 0.75 \%$ of annual Oregon statewide carbon emissions, and this does not include carbon in tree roots or the AGC losses due to the removal of trees $<21$ in $\mathrm{DBH}$. Removing nearly half of the carbon content from the large trees over 12,000 acres would create a carbon deficit in the live, dead, and soil carbon pools that will persist for many decades to the end of the century. However, left standing, these 43,445 large 
trees continue to grow, sequestering more carbon into long-term stores (Stephenson et al., 2014; Law et al., 2018; Domke et al., $2020)$. Older trees $(\sim 100$ years $)$ are the next generation of old growth and already possess qualities associated with large, old trees, such as large canopies, deep root systems, and thick, fireresistant bark.

\section{Co-Benefits of Carbon, Habitat, Biodiversity, Water Availability, Resilience to Climate Extremes}

High carbon conservation-priority forests support important components of biodiversity and are associated with increased water availability (McKinley et al., 2011; Perry and Jones, 2016; Berner et al., 2017; Law et al., 2018; Buotte et al., 2020). Large-diameter snags persist as standing snags for many years, providing valuable wildlife habitat, and account for a relatively high proportion of total snag biomass in temperate forests (Lutz et al., 2012). In PNW forests, large hollow trees, both alive and dead, are the most valuable for denning, shelter, roosting, and hunting by a wide range of animals (Bull et al., 2000; Rose et al., 2001). In the Interior Columbia River Basin, grand fir and western larch form the best hollow trees for wildlife uses (Rose et al., 2001). Downed hollow logs continue to serve as important hiding, denning, and foraging habitat on the forest floor (Bull et al., 1997; Bull et al., 2000). Large decaying wood influences basic ecosystem processes such as soil development and productivity, nutrient immobilization and mineralization, and nitrogen fixation (Harmon et al., 1986). Continuing to protect large trees in eastside forests provides the greatest benefit for carbon, habitat, and biodiversity.

Water availability and microclimatic buffering are also disproportionately affected by large trees and intact forests (Frey et al., 2016; Buotte et al., 2020). Forest canopies of the PNW buffer extremes of maximum temperature and vapor pressure deficit, with biologically beneficial consequences (Davis et al., 2019a). Removal of large trees quickly leads to a large increase in soil and canopy heating, which increases enough to impact photosynthesis (Kim et al., 2016), seedling survival, and regeneration (Kolb and Robberecht, 1996; Davis et al., 2019b). The climatic changes toward warmer and drier conditions expected in the next decades will likely increase forest stress and mortality (Allen et al., 2015). Eastside forests experienced hotter and drier conditions from 2003 to 2012 concentrated in the months of August and September, especially in drier forest type groups (i.e., ponderosa pine, juniper), whereas spring months (April-June) showed trends toward cooler and wetter conditions (Mildrexler et al., 2016). Projections suggest that proportionally, the largest changes in microclimatic buffering capacity will occur in lower elevation or dry forests, which currently have more limited buffering capacity (Davis et al., 2019a). In these drier regions, microclimatic buffering by forest canopies may create important microsites and refugia in a moisture-limited system (Meigs and Krawchuk, 2018). In an old growth ponderosa pine stand in eastern Oregon, $\sim 35 \%$ of the total daily water used from the upper $2 \mathrm{~m}$ was replaced by hydraulic redistribution from deep soil by deep-rooted larger trees in summer (Brooks et al., 2002). The bigger trees rarely reach $80 \%$ loss of hydraulic conductivity, and both mature pine and mesic Douglas-fir were better buffered from the effects of drought on photosynthesis compared with young pine ( $\sim 20$-year old $)$ due to full root development and larger stem capacitance in older trees (Kwon et al., 2018). Redistribution of deep soil water can increase seedling survival during summer drought when young trees lack the root development to reach deep soil water (Brooks et al., 2002). While large tree composition may have shifted today relative to European settlement times, these large trees nonetheless continue to perform important functional attributes related to water and climate such as carbon storage, hydraulic redistribution, shielding the understory from direct solar radiation, and providing wildlife habitat. These functional attributes of large trees, irrespective of species, characterize ecosystems through thousands to millions of years (Barnosky et al., 2017), and are not quickly replaced.

In mesic forest environments, microclimatic buffering and transpirational cooling are amplified because sites with higher moisture availability are better able to shift energy to latent as opposed to sensible heat fluxes (Dai et al., 1999; Mildrexler et al., 2011). During midday in full sun the surface temperature of a closed canopy moist forest is warmer than the temperature beneath the canopy which is protected from direct solar radiation (Thomas, 2011). Microclimates in moist forests are strongly linked to their closed-canopy structure (Chen et al., 1999; Aussenac, 2000). Removal of the overstory creates canopy openings that increase solar radiation penetration resulting in increased drying of the understory vegetation and the forest floor, and a thermal response of rising land surface temperatures (Chen et al., 1993, 1999). This alteration in the subcanopy thermal regime changes atmospheric mixing between the ground, subcanopy, and canopy, which in turn modifies the microclimate condition of the affected stand. Microclimate modifications associated with forest harvesting are expected to be greatest in moist forests and may affect resilience to climate change and increase the risk of occurrence and severity of wildfires (Lindenmayer et al., 2009). Maintaining mesic microclimates may give undisturbed moist forests and the species they support some inherent resilience to climate change. Moreover, an evaluation of the effects of water limitations on forest carbon cycling in the eastern Cascade Mountains found that grand fir radial growth was not strongly associated with variability in temperature or water variability (Berner and Law, 2015). A lengthening of the growing season may increase productivity in high-elevation grand fir stands. The microclimatic buffering, current and future potential carbon stores, and intact nature of previously unlogged grand fir and Douglas-fir forest types are co-benefits of protecting large trees that need to be considered in future management decisions.

\section{Potential Solutions}

The consequences of reducing protection of large trees are significant reduction in forest carbon stores and their climate mitigation, impacts on habitat for animals including birds, and 
resilience to a changing climate for decades to centuries to come. Given the rarity of large trees across the landscape, and their outsized role in storing carbon removed from the atmosphere, our findings call into question the value of removing large trees for forest modification in eastside forests.

If the 21-inch rule were retained on these lands, continued protection of the existing carbon stock would prevent large quantities of harvest related biogenic carbon from being released to the atmosphere. It is also essential to let a sufficient number of sub-21 inch trees remain to become additional large, effective carbon stores, and assure that carbon accumulation continues in these forests. Rather than weakening the 21 -inch rule, we suggest strengthening this important measure and expanding large tree protections to other western United States public lands that have been adversely affected by a similar history of large-tree logging. Protecting and growing more large trees is the most effective near-term option for accumulating more carbon out of the atmosphere, and will benefit other ecosystem services as well.

Some public lands (local, state, and federal) could become part of a designated reserve system that includes intact forest landscapes, and carbon rich forests, that hold most of these large, older trees. This is an appropriate use of public lands because the services they provide including biodiversity, water retention, carbon accumulation and storage, and regional cooling by evapotranspiration serve the public interest, and promote sustainable economies that benefit from land protection and restoration.

The critical need to adapt to more wildfire in the west is congruent with protecting large-trees in fire-prone forests. Older forests experience lower fire-severity compared with younger, intensively managed forests, even during extreme weather conditions (Zald and Dunn, 2018). A shift in policy and management from restoring ecosystems based on historical baselines to adapting to changing fire regimes and from unsustainable defense of the wildland-urban interface to developing fire-adapted communities is needed (Schoennagel et al., 2017). Improved fire and forest management is part of the solution, but the most effective changes in terms of protection of people and property, will be near homes and on private property. Prioritizing federal fuel treatments around communities and creating better mechanisms for reducing fuels on private land can help reduce home loss and better protect communities (Moritz et al., 2014; Schoennagel et al., 2017). Given the natural role of fire in the West, managing more wild and prescribed fires with a range of severities will help reduce future wildfire threats and increase ecological benefits in many systems (Schoennagel et al., 2017).

Eastside forests are surrounded predominantly by rural communities. For production forests, lengthening the forest cycle will keep a larger amount of carbon in trees and soils rather than in the atmosphere (Law et al., 2018). Rather than coupling funding of forest restoration or community payments to logging large trees and disturbing older forests, new policies could be enacted that compensate rural communities for protecting large trees in older forests and some of the younger trees that will become large with their associated carbon stores.
To implement such policies, the amount to be paid to a community needs to be marginally greater than the revenue earned from cutting these large trees and the older forests in which they are located. Policies that provide compensation for setting aside reserves and individual trees with microhabitats are already in place in Europe (European Commission, 2015). Because this service benefits society as a whole and is an irreplaceable part of the natural climate solutions framework urgently needed for climate stabilization, the payment funds should come from the treasury since all citizens benefit from carbon accumulation by these trees and forests. With over half of Oregon's forest east of the Cascade Mountains crest, these forests are key to the State's climate mitigation and biodiversity conservation goals.

\section{CONCLUSION}

Conducting a quantitative assessment using empirical data has determined the large carbon stock that would be lost and the resulting climate consequences if these large trees are harvested. Research indicates that 2021 begins a pivotal decade for humanity to transition off of fossil-fuels (IPCC, 2018) and move "to achieve ... stabilization of greenhouse gas concentrations in the atmosphere at a level that would prevent dangerous anthropogenic interference with the climate system." (UNFCCC, 1992, Article 2). To meet net-zero carbon goals by 2050 , it is estimated that reductions in net carbon emissions must be $7.6 \%$ per year over the decade of the 2020s (UNEP, 2019). This is most readily accomplished by reducing fossil fuel, bioenergy and industrial carbon dioxide emissions while simultaneously accumulating more carbon dioxide by protecting existing older forests that contain the largest share of carbon, and by allowing more forests to continue to accumulate carbon through proforestation (IUCN, 2020). Proforestation allows existing forests to continue growing without harvest or other management practices so that more trees can reach the large tree size that accumulates more carbon in the near and long term than do reforestation and afforestation (Moomaw et al., 2019). No additional land is required as is the case with afforestation, and proforestation is the lowest cost opportunity for reaching the zero net carbon goal by 2050. In fire-prone forests such as in our study area, a diameter limit strikes the balance between protecting the most fire-resistant trees that store the most carbon and allowing fuels reduction with reintroduction of fire in dry biophysical environments. Intact mesic forests are ideal locations for proforestation. Harvesting large trees will add very large amounts of biogenic carbon to the atmosphere (Harris et al., 2016), and make the net zero carbon goal difficult or impossible for Oregon to achieve. The young trees will never be able to recover and accumulate the amount of carbon that is in the growing and older forests during these next critical decades, and will only equal current levels a century or more from now.

Protecting large trees to help stabilize climate is critically important for managing forest ecosystems as social-ecological 
systems. Knowledge of the disproportionately large amount of carbon stored in a small fraction of trees creates an opportunity to engage the public, decision makers, and forest managers in their importance as an integral part of the climate solution.

\section{DATA AVAILABILITY STATEMENT}

Publicly available datasets were analyzed in this study and are available through the FIA DataMart: https://apps.fs.usda.gov/fia/ datamart/CSV/datamart_csv.html.

\section{AUTHOR CONTRIBUTIONS}

$\mathrm{DM}$ and $\mathrm{LB}$ conceived the ideas and designed the study with critical suggestions from BL and RB. DM and LB collected the data. LB processed the data and carried out the modeling. $\mathrm{DM}$ and LB analyzed the data and led the writing of the manuscript. $\mathrm{BL}, \mathrm{RB}$, and $\mathrm{WM}$ assisted with writing, and contributed critically to the drafts. All authors gave final approval for publication.

\section{REFERENCES}

Agee, J. K., and Skinner, C. N. (2005). Basic principles of forest fuel reduction treatments. For. Ecol. Manage. 211, 83-96. doi: 10.1016/j.foreco.2005.01.034

Allen, C. D., Breshears, D. D., and McDowell, N. G. (2015). On underestimation of global vulnerability to tree mortality and forest die-off from hotter drought in the Anthropocene. Ecosphere 6:129. doi: 10.1890/ES15-00203.1

Allen, C. D., Savage, M. S., Falk, D. A., Suckling, K. F., Swetnam, T. W., Schulke, T., et al. (2002). Ecological restoration of southwestern ponderosa pine ecosystems: a broad perspective. Ecol. Appl. 12, 1418-1433. doi: 10.1890/1051-0761(2002) 012[1418:erospp]2.0.co;2

Aussenac, G. (2000). Interactions between forest stands and microclimate: ecophysiological aspects and consequences for silviculture. Ann. For Sci. 57, 287-301. doi: 10.1051/forest:2000119

Barnosky, A. D., Hadly, E. A., Gonzalez, P., Head, J., Polly, P. D., Lawing, A. M., et al. (2017). Merging paleobiology with conservation biology to guide the future of terrestrial ecosystems. Science 355:eaah4787. doi: 10.1126/science. aah4787

Beiler, K. J., Simard, S. W., and Durall, D. M. (2015). Topology of Rhizopogon spp. mycorrhizal meta-networks in xeric and mesic old-growth interior Douglas-fir forests. J. Ecol. 103, 616-628. doi: 10.1111/1365-2745.12387

Berner, L. T., and Law, B. E. (2015). Water limitations on forest carbon cycling and conifer traits along a steep climatic gradient in the Cascade Mountains, Oregon. Biogeosciences 12, 6617-6635. doi: 10.5194/bg-12-6617-2015

Berner, L. T., and Law, B. E. (2016). Plant traits, productivity, biomass and soil properties from forest sites in the Pacific Northwest, 1999-2014. Sci. Data 3:160002.

Berner, L. T., Law, B. E., and Hudiburg, T. W. (2017). Water availability limits tree productivity, carbon stocks, and carbon residence time in mature forests across the western US. Biogeosciences 14, 365-378. doi: 10.5194/bg-14-365-2017

Birdsey, R., Pregitzer, K., and Lucier, A. (2006). Forest carbon management in the United States: 1600-2100. J. Environ. Qual. 35, 1461-1469. doi: 10.2134/ jeq2005.0162

Birdsey, R. A., Dugan, A. J., Healey, S. P., Dante-Wood, K., Zhang, F., Mo, G., et al. (2019). Assessment of the Influence of Disturbance, Management Activities, and Environmental Factors on Carbon Stocks of U.S. National Forests. Gen. Tech. Rep. RMRS-GTR-402. Fort Collins, CO: U.S. Department of Agriculture.

\section{FUNDING}

This research was supported by United States Department of Energy (Grant DE-SC0012194) and Agriculture and Food Research Initiative of the USDA National Institute of Food and Agriculture (Grant numbers 2014-67003-22065 and 201435100-22066) for our North American Carbon Program study, "Carbon cycle dynamics within Oregon's urban-suburbanforested-agricultural landscapes." WM received support from Rockefeller Brothers Fund. DM received support from Eastern Oregon Legacy Lands.

\section{ACKNOWLEDGMENTS}

Thanks to Dr. Mark Harmon for supporting the initiation of this research.

\section{SUPPLEMENTARY MATERIAL}

The Supplementary Material for this article can be found online at: https://www.frontiersin.org/articles/10.3389/ffgc.2020. 594274/full\#supplementary-material

Bivand, R., Keitt, T., and Rowlingson, B. (2019). rgdal: Bindings for the 'Geospatial' Data Abstraction Library. $R$ package version 1.4-8. Available online at: https: //CRAN.R-project.org/package=rgdal (accessed October 25, 2019).

Bivand, R., and Lewin-Koh, N. (2019). maptools: Tools for Handling Spatial Objects. $R$ package version 0.9.9. Available online at: https://CRAN.R-project. org/package $=$ maptools (accessed February 2, 2019).

Brooks, J. R., Meinzer, F. C., Coulombe, R., and Gregg, J. (2002). Hydraulic redistribution of soil water during summer drought in two contrasting Pacific Northwest coniferous forests. Tree Physiol. 22, 1107-1117. doi: 10.1093/ treephys/22.15-16.1107

Brown, R. T., Agee, J. K., and Franklin, J. F. (2004). Forest restoration and fire: principles in the context of place. Conserv. Biol. 18, 903-912. doi: 10.1111/j. 1523-1739.2004.521_1.x

Bull, E. L., Akenson, J. J., and Henjum, M. J. (2000). Characteristics of black bear dens in trees and logs in northeastern Oregon. Northw. Naturalist 81, 148-153. doi: $10.2307 / 3536825$

Bull, E. L., Heater, T. W., and Shepherd, J. F. (2005). Habitat selection by the American Marten in Northeastern Oregon. Northwest Sci. 79, 36-42.

Bull, E. L., Parks, C. G., and Torgersen, T. R. (1997). Trees and Logs Important to Wildlife in the Interior Columbia River Basin. Gen. Tech. Rep. PNW-GTR-391. Portland, OR: U.S. Department of Agriculture.

Buotte, P. C., Law, B. E., Ripple, W. J., and Berner, L. T. (2020). Carbon sequestration and biodiversity co-benefits of preserving forests in the western United States. Ecol. Appl. 30:e02039. doi: 10.1002/eap.2039

Chen, J., Franklin, J. F., and Spies, T. A. (1993). Contrasting microclimates among clearcut, edge, and interior of old-growth Douglas-fir forest. Agric. Forest Meteorol. 63, 219-237. doi: 10.1016/0168-1923(93)90061-1

Chen, J., Saunders, S. C., Crow, T. R., Naiman, R. J., Brosofske, K. D., Mroz, G. D., et al. (1999). Microclimate in forest ecosystem and landscape ecology. BioScience 49, 288-297. doi: 10.2307/1313612

Cochran, P. H. (1985). Site Index, Height Growth, Normal Yields and Stocking Levels for Larch in Oregon and Washington. Research Paper PNW-RP-424. Portland, OR: U.S. Department of Agriculture.

Cook-Patton, S. C., Leavitt, S. M., Gibbs, D., Harris, N. L., Lister, K., AndersonTeixeira, K. J., et al. (2020). Mapping carbon accumulation potential from global natural forest regrowth. Nature 585, 545-550. doi: 10.1038/s41586-0202686-x 
Dai, A., Trenberth, K. E., and Karl, T. R. (1999). Effects of clouds, soil moisture, precipitation, and water vapor on diurnal temperature range. J. Clim. 12, 2451-2473. doi: 10.1175/1520-0442(1999)012<2451:eocsmp > 2.0.co;2

Daly, C., Halbleib, M., Smith, J. I, Gibson, W. P., Dogget, M. K., Taylor, G. H., et al. (2008). Physiographically sensitive mapping of climatological temperature and precipitation across the conterminous United States. Int. J. Climatol. 28, 2031-2064. doi: 10.1002/joc.1688

Davis, K. T., Dobrowski, S. Z., Higuera, P. E., Holden, Z. A., Veblen, T. T., Rother, M. T., et al. (2019b). Wildfires and climate change push low-elevation forests across a critical climate threshold for tree regeneration. Proc. Natl. Acad. Sci. U.S.A. 116, 6193-6198. doi: 10.1073/pnas.1815107116

Davis, K. T., Dobrowski, S. Z., Holden, Z. A., Higuera, P. E., and Abatzoglou, J. T. (2019a). Microclimatic buffering in forests of the future: the role of local water balance. Ecography 42, 1-11. doi: 10.1111/ecog.03836

Dawle, M., and Srinivasan, A. (2019). data.table: Extension of 'data.frame'. $R$ package version 1.12.8. Available online at: https://CRAN.R-project.org/ package $=$ data.table (accessed October 17, 2019).

Depro, B. M., Murray, B. C., Alig, R. J., and Shanks, A. (2008). Public land, timber harvests, and climate mitigation: quantifying carbon sequestration potential on U.S. public timberlands. For. Ecol. Manage. 225, 1122-1134. doi: 10.1016/j. foreco.2007.10.036

Dilling, L., Birdsey, R., and Pan, Y. (2013). "Opportunities and challenges for carbon management on U.S. public lands," in Land Use and the Carbon Cycle: Advances in Integrated Science, Management and Policy, eds D. G. Brown, D. T. Robinson, N. H. F. French, and B. C. Reed (Cambridge: Cambridge Press), 455-476. doi: 10.1017/cbo9780511894824.023

Domke, G. M., Oswalt, S. N., Walters, B. F., and Morin, R. S. (2020). Tree planting has the potential to increase carbon sequestration capacity of forests in the United States. Proc. Natl. Acad. Sci. U.S.A. 117, 24649-24651. doi: 10.1073/pnas. 2010840117

Dugan, A. J., Birdsey, R., Healey, S. P., Pan, Y., Zhang, F., Mo, G., et al. (2017). Forest sector carbon analyses support land management planning and projects: assessing the influence of anthropogenic and natural factors. Clim. Change 144, 207-220. doi: 10.1007/s10584-017-2038-5

EPA (2020). Draft Inventory of U.S. Greenhouse Gas Emissions and Sinks: 19902018. EPA 430-P-20-001. Washington, DC: U.S. Environmental Protection Agency, 719.

European Commission (2015). Natura 2000 and Forests. Part I-II. Technical Report-2015-088. Brussels: EU Commission Environment.

Fargione, J. E., Bassett, S., Boucher, T., Bridgham, S. D., Conant, R. T., Cook-Patton, S. C., et al. (2018). Natural climate solutions for the United States. Sci. Adv. 4:eaat1869. doi: 10.1126/sciadv.aat186

Frey, S. J. K., Hadley, A. S., Johnson, S. L., Schulze, M., Jones, J. A., and Betts, M. G. (2016). Spatial models reveal the microclimate buffering capacity of old-growth forests. Sci. Adv. 2:e1501392. doi: 10.1126/sciadv.1501392

Friedlingstein, P., Jones, M. W., O’Sullivan, M., Andrew, R. M., Hauck, J., Peter, G. P., et al. (2019). Global carbon budget 2019. Earth Syst. Sci. Data 11, 1783-1838. doi: 10.5194/essd-11-1783-2019

Gholz, H. L., Grier, C. C., Campbell, A. G., and Brown, A. T. (1979). Equations for Estimating Biomass and Leaf Area of Plants in the Pacific Northwest. Res. Pap. 41, Forestry Research Laboratory. Corvallis: Oregon State University, 38.

Greenwald, D. N., Crocker-Bedford, D. C., Broberg, L., Suckling, K. E., and Tibbitts, T. (2005). A review of Northern Goshawk habitat selection in the home range and implications for forest management in the Western United States. Wildl. Soc. Bull. 33, 120-129. doi: 10.2307/3784847

Griscom, B. W., Adams, J., Ellis, P. W., Houghton, R. A., Lomax, G., Miteva, D. A., et al. (2017). Natural climate solutions. Proc. Natl. Acad. Sci. U.S.A. 114, 11645-11650. doi: 10.1073/pnas.1710465114

Hagmann, R. K., Franklin, J. F., and Johnson, K. N. (2013). Historical structure and composition of ponderosa pine and mixed-conifer forests in south-central Oregon. For. Ecol. Manag. 304, 492-504. doi: 10.1016/j.foreco.2013.04.005

Harmon, M. E., Bible, K., Ryan, M. G., Shaw, D. C., Chen, H., Klopatek, J., et al. (2004). Production, respiration, and overall carbon balance in an oldgrowth Pseudotsuga-Tsuga forest ecosystem. Ecosystems 7, 498-512. doi: 10. 1007/s10021-004-0140-9

Harmon, M. E., Franklin, J. F., Swanson, F. J., Sollins, P., Gregory, S. V., Lattin, J. D., et al. (1986). Ecology of coarse woody debris in temperate ecosystems. Adv. Ecol. Res. 15, 133-302. doi: 10.1016/S0065-2504(03)34002-4
Harmon, M. E., Woodall, C. W., Fasth, B., and Sexton, J. (2008). Woody Detritus Density and Density Reduction Factors for Tree Species in the United States: A Synthesis. Gen. Tech. Rep. NRS-29. Newtown Square, PA: U.S. Department of Agriculture, 84.

Harris, N. L., Hagen, S. C., Saatchi, S. S., Pearson, T. R. H., Woodall, C. W., Domke, G. M., et al. (2016). Attribution of net carbon change by disturbance type across forest lands of the conterminous United States. Carbon Balance Manag. 11:24. doi: 10.1186/s13021-016-0066-5

Henjum, M. G., Karr, J. R., Bottom, D. L., Perry, D. A., Bednarz, J. C., Wright, S. G., et al. (1994). Interim Protection for Late Successional Forest, Fisheries and Watersheds: National Forests East of the Cascade Crest, Oregon and Washington. Bethesda, MD: Wildlife Society.

Hessburg, P. F., Charnley, S., Wendel, K. L., White, E. M., Spies, T. A., Singleton, P. H., et al. (2020). The 1994 Eastside Screens-Large Tree Harvest Limit: Synthesis of Science Relevant to Forest Planning 25 years Later. Portland, OR: USDA.

Hijmans, R. J. (2019). raster: Geographic Analysis and Modeling. $R$ package version 3.0-12. Available online at: http://CRAN.R-project.org/package=raster (accessed August 22, 2019).

Hudiburg, T., Law, B., Turner, D. P., Campbell, J., Donato, D. C., and Duane, M. (2009). Carbon dynamics of Oregon and Northern California forests and potential land-based carbon storage. Ecol. Appl. 19, 163-180. doi: 10.1890/072006.1

Hudiburg, T. W., Law, B. E., Moomaw, W. R., Harmon, M. E., and Stenzel, J. E. (2019). Meeting GHG reduction targets requires accounting for all forest sector emissions. Environ. Res. Lett. 14, 095005. doi: 10.1088/1748-9326/ab28bb

Interior Columbia Basin Ecosystem Management Project (2000). Supplemental Draft Environmental Impact Statement. Boise: ICBEMP.

IPCC (2018). "Summary for policymakers," in Global Warming of 1.5oC, An IPCC Special Report, eds V. Masson Delmotte, P. Zhai, H.-O. P. Rtner, D. Roberts, J. Skea, P. R. Shukla, et al. (Geneva: World Meteorological Organization), 32.

IUCN (2020). International Union for the Conservation of Nature. Cyril Kormos, Brendan Mackey, Russel Mittermeir, Virginia Young, Primary Forests: A Priority Nature-Based Solution. Available online at: https://www.iucn.org/crossroadsblog/202003/primary-forests-a-priority-nature-based-solution (accessed August 5, 2020)

Jenkins, J., Chojnacky, D., Heath, L., and Birdsey, R. (2004). Comprehensive Database of Diameter-Based Biomass Regressions for North American Tree Species. Gen Tech Rep NE-319. Newtown Square, PA: U.S. Department of Agriculture.

Johnson, C. G., and Clausnitzer, R. R. (1992). Plant Associations of the Blue and Ochoco Mountains. R6-ERW-T-036-92. Portland, OR: USDA Forest Service Pacific Northwest Region.

Johnston, J. D., Bailey, J. D., and Dunn, C. J. (2016). Influence of fire disturbance and biophysical heterogeneity on pre-settlement ponderosa pine and mixed conifer forests. Ecosphere 7:e01581. doi: 10.1002/ecs2.1581

Johnston, J. D., Dunn, C. J., Vernon, M. J., Bailey, J. D., Morrissette, B. A., and Morici, K. E. (2018). Restoring historical forest conditions in a diverse inland Pacific Northwest landscape. Ecosphere 9:e02400. doi: 10.1002/ecs2.2400

Kauppi, P. E., Birdsey, R. A., Pan, Y., Ihalainen, P., Nöjd, P., and Lehtonen, A. (2015). Effects of land management on large trees and carbon stocks. Biogeosciences 12, 855-886. doi: 10.5194/bg-12-855-2015

Kerns, B. K., Powell, D. C., Mellmann-Brown, S., Carnwath, G., and Kim, J. B. (2017). Effects of projected climate change on vegetation in the Blue Mountains ecoregion, USA. Clim. Serv. 10, 33-43. doi: 10.1016/j.cliser.2017.07.002

Kim, Y., Still, C. J., Hanson, C. V., Kwon, H., Greer, B. T., and Law, B. E. (2016). Canopy skin temperature variations in relation to climate, soil temperature, and carbon flux at a ponderosa pine forest in central Oregon. Agr. Forest Meteorol. 226, 161-173. doi: 10.1016/j.agrformet.2016.06.001

Kolb, P. F., and Robberecht, R. (1996). High temperature and drought stress effects on survival of Pinus ponderosa seedlings. Tree Physiol. 16, 665-672. doi: 10.1093/treephys/16.8.665

Krankina, O. N., Harmon, M. E., Schnekenburger, F. S., and Sierra, C. A. (2012). Carbon balance on federal forest lands of Western Oregon and Washington: the impact of the Northwest Forest Plan. For. Ecol. Manage. 286, 171-182. doi: 10.1016/j.foreco.2012.08.028

Kwon, H., Law, B. E., Thomas, C. K., and Johnson, B. G. (2018). The influence of hydrological variability on inherent water use efficiency in forests 
of contrasting composition, age, and precipitation regimes in the Pacific Northwest. Agric. For. Meteorol. 249, 488-500. doi: 10.1016/j.agrformet.2017. 08.006

Lamlom, S., and Savidge, R. (2003). A reassessment of carbon content in wood: variation within and between 41 North American species. Biomass Bioenergy 25, 381-388. doi: 10.1016/S0961-9534(03)00033-3

Law, B. E., Hudiburg, T. W., Berner, L. T., Kent, J. J., Buotte, P. C., and Harmon, M. (2018). Land use strategies to mitigate climate change in carbon dense temperate forests. Proc. Nat. Acad. Sci. U.S.A. 115, 3663-3668. doi: 10.1073/ pnas. 1720064115

Lindenmayer, D. B., Hunter, M. L., Burton, P. J., and Gibbons, P. (2009). Effects of logging on fire regimes in moist forests. Conserv. Lett. 2, 271-277. doi: 10.1111/j.1755-263x.2009.00080.x

Lindenmayer, D. B., and Laurance, W. F. (2017). The ecology, distribution, conservation and management of large old trees. Biol. Rev. 92, 1434-1458. doi: 10.1111/brv.12290

Lindenmayer, D. B., Laurance, W. F., Franklin, J. F., Likens, G. E., Banks, S. C., Blanchard, W., et al. (2014). New policies for old trees: averting a global crisis in a keystone ecological structure. Conserv. Lett. 7, 61-69. doi: 10.1111/conl. 12013

Lutz, J. A., Furniss, T. J., Johnson, D. J., Davies, S. J., Allen, D., Alonso, A., et al. (2018). Global importance of large-diameter trees. Glob. Ecol. Biogeogr. 27, 849-864. doi: 10.1111/geb.12747

Lutz, J. A., Larson, A. J., Swanson, M. E., and Freund, J. A. (2012). Ecological importance of large-diameter trees in a temperate mixed-conifer forest. PLoS One 7:e36131. doi: 10.1371/journal.pone.0036131

Luyssaert, S., Schulze, E.-D., Börner, A., Knohl, A., Hessenmöller, D., Law, B. E., et al. (2008). Old-growth forests as global carbon sinks. Nature 455, 213-215. doi: 10.1038/nature07276

Masek, J. G., Cohen, W. B., Leckie, D., Wulder, M. A., Vargas, R., de Jong, B., et al. (2011). Recent Rates of Forest Harvest and Conversion in North America. J. Geophy. Res. 116:G00K03. doi: 10.1029/2010JG001471

McGuire, J. L., Lawler, J. J., McRae, B. H., Nuñez, T., and Theobald, D. M. (2016). Achieving climate connectivity in a fragmented landscape. Proc. Natl. Acad. Sci. U.S.A. 113, 7195-7200. doi: 10.1073/pnas.1602817113

McKinley, D. C., Ryan, M. G., Birdsey, R. A., Giardina, C. P., Harmon, M. E., Heath, L. S., et al. (2011). A synthesis of current knowledge on forests and carbon storage in the United States. Ecol. Appl. 21, 1902-1924. doi: 10.1890/100697.1

Means, J. E., Hansen, H. A., Koerper, G. J., Alaback, P. B., and Klopsch, M. W. (1994). Software for Computing Plant Biomass-BIOPAK Users Guide. Portland, OR: U.S. Department of Agriculture.

Meigs, G. W., and Krawchuk, M. A. (2018). Composition and structure of forest fire refugia: what are the ecosystem legacies across burned landscapes? Forests 9:243. doi: 10.3390/f9050243

Merschel, A., Vora, R. S., and Spies, T. (2019). Conserving dry old-growth forest in Central Oregon, USA. J. For. 117, 128-135. doi: 10.1093/jofore/ fvy085

Merschel, A. G., Spies, T. A., and Heyerdahl, E. K. (2014). Mixed-conifer forests of central Oregon: effects of logging and fire exclusion vary with environment. Ecol. Appl. 24, 1670-1688. doi: 10.1890/13-1585.1

Mildrexler, D. J., Yang, Z., and Cohen, W. B. (2016). A forest vulnerability index based on drought and high temperatures. Rem. Sens. Environ. 173, 314-325. doi: 10.1016/j.rse.2015.11.024

Mildrexler, D. J., Zhao, M., and Running, S. W. (2011). A global comparison between station air temperatures and MODIS land surface temperatures reveals the cooling role of forests. J. Geophys. Res. 116:G03025. doi: 10.1029/ 2010JG001486

Millar, C. I., Stephenson, N. L., and Stephens, S. L. (2007). Climate change and forests of the future: managing in the face of uncertainty. Ecol. Appl. 17, 2145-2151. doi: 10.1890/06-1715.1

Mitchell, S. R., Harmon, M. E., and O’Connell, K. E. B. (2009). Forest fuel reduction alters fire severity and long-term carbon storage in three Pacific Northwest ecosystems. Ecol. Appl. 19, 643-655. doi: 10.1890/08-0501.1

Moomaw, W. R., Masino, S. A., and Faison, E. K. (2019). Intact forests in the United States: proforestation mitigates climate change and serves the greatest good. Front. For. Glob. Change 2:27. doi: 10.3389/ffgc.2019. 00027
Moritz, M. A., Batllori, E., Bradstock, R. A., Gill, A. M., Handmer, J., Hessburg, P. F., et al. (2014). Learning to coexist with wildfire. Nature 515, 58-66. doi: 10.1038 /nature13946

Noss, R. F., Franklin, J. F., Baker, W. L., Schoennagel, T., and Moyle, P. B. (2006). Managing fire-prone forests in the western United States. Front. Ecol. Environ. 4:481-487. doi: 10.1890/1540-929520064[481:MFFITW]2.0.CO;2

O’Connell, B. M., Conkling, B. L., Wilson, A. M., Burrill, E. A., Turner, J. A., Pugh, S. A., et al. (2017). The Forest Inventory and Analysis Database: Database Description and User Guide Version 7.0 for Phase 2. Washington, DC: U.S. Department of Agriculture, 830.

Pan, Y., Birdsey, R. A., Fang, J., Houghton, R., Kauppi, P. E., Kurz, W. A., et al. (2011). A large and persistent carbon sink in the World's forests. Science 333, 988-993. doi: 10.1126/science.1201609

Perry, T. D., and Jones, J. A. (2016). Summer streamflow deficits from regenerating Douglas-fir forests in the Pacific Northwest, USA. Ecohydrology 10:e1790. doi: 10.1002/eco. 1790

Peterson, D. L., and Waring, R. H. (1994). Overview of the Oregon transect ecosystem research project. Ecol. Appl. 4, 211-225. doi: 10.2307/1941928

R Core Team (2020). R: A Language and Environment for Statistical Computing. Vienna: R Foundation for Statistical Computing.

Rainville, R., White, R., and Barbour, J. (2008). Assessment of Timber Availability from Forest Restoration within the Blue Mountains of Oregon. Gen. Tech. Rep. PNW-GTR-752. Portland, OR: USDA, 65.

Ripple, W. J., Wolf, C., Newsome, T. M., Barnard, P., and Moomaw, W. B. (2020). World scientists' warning of a climate emergency. BioScience 70, 8-12. doi: 10.1093/biosci/biz088

Rockström, J., Steffen, W., Noone, K., Persson, A., Chapin, F. S. III, Lambin, E., et al. (2009). Planetary boundaries: exploring the safe operating space for humanity. Nature 461, 472-475.

Rose, C. L., Marcot, B. G., Mellen, T. K., Ohmann, J. L., Waddell, K. L., Lindely, D. L., et al. (2001). “"Decaying wood in Pacific Northwest forests: concepts and tools for habitat management" Pages," in Wildlife-Habitat Relationships in Oregon and Washington, eds D. H. Johnson and T. A. O'Neil (Corvallis, OR: Oregon State University Press), 580-623.

Ross, R. J. (2010). Wood Handbook: Wood as an Engineering Material. USDA Forest Service, Forest Products Laboratory, General Technical Report FPL-GTR-190, 2010: 509 p. 1 v. 190. Madison: United States Department of Agriculture Forest Service.

Ruefenacht, B., Finco, M. V., Nelson, M. D., Czaplewski, R., Helmer, E. H., Blackard, J. A., et al. (2008). Conterminous U.S. and alaska forest type mapping using forest inventory and analysis data. Photogramm. Eng. Rem. Sens. 74, 1379-1388. doi: 10.14358/pers.74.11.1379

Schoennagel, T., Balch, J. K., Brenkert-Smith, H., Dennison, P. E., Harvey, B. J., Krawchuk, M. A. K., et al. (2017). Adapt to more wildfire in western North American forests as climate changes. Proc. Natl Acad. Sci. U.S.A. 114, 45824590. doi: 10.1073/pnas.1617464114

Sheil, D. (2018). Forests, atmospheric water and an uncertain future: the new biology of the global water cycle. For. Ecosyst. 5:19.

Simard, S. W., Roach, W. J., Defrenne, C. E., Pickles, B. J., Snyder, E. N., Robinson, A., et al. (2020). Harvest intensity effects on carbon stocks and biodiversity are dependent on regional climate in Douglas-fir forests of British Columbia. Front. For. Glob. Change 3:88. doi: 10.3389/ffgc.2020.00088

Stephenson, N. L., Das, A. J., Condit, R., Russo, S. E., Baker, P. J., Beckman, N. J., et al. (2014). Rate of tree carbon accumulation increases continuously with tree size. Nature 507, 90-93.

Thomas, C. K. (2011). Variability of subcanopy flow, temperature, and horizontal advection in moderately complex terrain. Boundarawry Layer Meteorol. 139, 61-81. doi: 10.1007/s10546-010-9578-9

Turner, D. P., Ritts, W. D., Yang, Z., Kennedy, R. E., Cohen, W. B., Duane, M. V., et al. (2011). Decadal trends in net ecosystem production and net ecosystem carbon balance for a regional socioecological system. For. Ecol. Manag. 262, 1318-1325. doi: 10.1016/j.foreco.2011.06.034

UNEP (2019). UN Environment Programme Emissions Gap Report. Available online at: https://www.unenvironment.org/resources/emissions-gap-report2019 (accessed August 4, 2020)

UNFCCC (1992). Un Framework Convention on Climate Change Article 2. Available online at: unfccc.int/resource/docs/convkp/conveng.pdf (accessed August 4, 2020). 
USDA Forest Service (1995). Appendix N, Eastside Screens. In: Appendix $B$-Revised Interim management direction establishing riparian, ecosystem, and wildlife standards for timber sales. Regional Forester's Forest Plan Amendment \#2. Portland, OR: U.S. Department of Agriculture Forest Service.

Van Tuyl, S., Law, B. E., Turner, D. P., and Giterman, A. I. (2005). Variability in net primary production and carbon storage in biomass across Oregon forests an assessment integrating data from forest inventories, intensive sites, and remote sensing. For. Ecol. Manage. 209, 273-291. doi: 10.1016/j.foreco.2005. 02.002

Wales, B. C., Suring, L. H., and Hemstrom, M. A. (2007). Modeling potential outcomes of fire and fuel management scenarios on the structure of forested habitats in northeast Oregon, USA. Landscape Urban Plan. 80, 223-236. doi: 10.1016/j.landurbplan.2006.10.006

Wickham, H. (2016). ggplot2: Elegant Graphics for Data Analysis. New York, NY: Springer-Verlang.

Wisdom, M. J., Holthausen, R. S., Wales, B. C., Hargis, C. D., Saab, V. A., Lee, D. C., et al. (2000). Source Habitats for Terrestrial Vertebrates of Focus in the Interior Columbia Basin: Broad-Scale Trends and Management Implications, 3 vols.
Gen. Tech. Rep. PNW-GTR-485. Portland, OR: U.S. Department of Agriculture Forest Service.

Zald, H. S. J., and Dunn, C. J. (2018). Severe fire weather and intensive forest management increase fire severity in a multi-ownership landscape. Ecol. Appl. 28, 1068-1080. doi: 10.1002/eap.1710

Conflict of Interest: LB was employed by EcoSpatial Services L.L.C.

The remaining authors declare that the research was conducted in the absence of any commercial or financial relationships that could be construed as a potential conflict of interest.

Copyright (C) 2020 Mildrexler, Berner, Law, Birdsey and Moomaw. This is an openaccess article distributed under the terms of the Creative Commons Attribution License (CC BY). The use, distribution or reproduction in other forums is permitted, provided the original author(s) and the copyright owner(s) are credited and that the original publication in this journal is cited, in accordance with accepted academic practice. No use, distribution or reproduction is permitted which does not comply with these terms. 